\title{
LAW AND MORALITY? \\ SOME THEOLOGICAL PERSPECTIVES
}

\author{
Dirkie Smit \\ Faculty of Theology \\ Stellenbosch University
}

\begin{abstract}
The essay reflects on the well-known poem "What abou' de lô?(1961) by Adam Small in order to raise some aspects of the complex relationship between law and morality. Written in the years of struggle against the apartheid system, the poem clearly questioned the legitimacy of so-called positive law, suggesting that legality and legitimacy are not necessarily identical and that justice is not merely the application of the existing law of the day. But what is then the alternative, what could be the norm with which to measure the law? Three possible answers to this question are considered, all of them implicitly suggested by the poem - some form of moral law, some notion of justice, or some form of divine or revealed law. All three are represented and defended by influential theoretical traditions, yet all three also lead to ambiguities and new problems. In conclusion, some brief theological comments are offered.
\end{abstract}

Keywords: Morality, Law, Justice, Moral Law, Adam Small

\section{What abou' de lô?}

Some decades ago Adam Small, a distinguished colleague at the University of the Western Cape - first in Philosophy, later in Social Work - published his "What abou' de lô?" (Kitaar my kruis, 1961).

From a Christian theological perspective, this poem raises several themes regarding the question of this consultation, ${ }^{1}$ the complex relationship between law and morality.

Reduced to mere prosaic phrases, without the repetition and rhetorical power of the original poetry, it reads:

\footnotetext{
This paper was read on request during an Interdisciplinary Consultation hosted at the University of the Western Cape by the Department of Religion and Theology, the Faculty of Law and the Ecumenical Foundation of Southern Africa (EFSA), on August 3, 2007. The theme of the Consultation was "What is law without morality?" All the other contributions were presented from legal perspectives, and this was the only one from a theological perspective. Other speakers included Constitutional Court Judges Laurie Ackermann and Yvonne Mokgoro, and legal scholars like professors Drucilla Cornell, Roger Berkowitz, Karin van Merle and Lourens du Plessis.
} 


\author{
Diana was ' $n$ wit nôi \\ Martyn was 'n bryn boy \\ deyfell in love

\section{sê Diana se mense \\ sê Martin se mense \\ sê almal die mense \\ what abou' de lô}

sê Martin sê Diana watte lô

God's lô

man's lô

devil's lô

watte lo

sê die mense net

de lô

what abou' de lô

Diana was 'n wit nô $i$

Martyn was ' $n$ bryn boy

dey go to jail

sê Diana se mense

sê Martin se mense

sê almal die mense

we tol' you mos

sê Martin sê Diana

what you tol'

what God tell

what man tell

\author{
what devil tell \\ what you tol' \\ sê die mense net \\ de lô \\ what abou' de lô \\ Diana was 'n wit nô $i$ \\ Martyn was 'n bryn boy
}

Diana commit suicide

Martin commit suicide

Diana en Martin commit suicide

\begin{abstract}
sê Diana se mense
sê Martin se mense

sê almal die mense

o God behoed
\end{abstract}

Martin en Diana died for de lô

God's lô

man's lô

devil's lô

watte lô

sê die mense net

de lô

what abou' de lô

\section{Positive Law?}

It is obvious that Adam Small is raising critical questions concerning the legitimacy of existing or so-called positive law. Does the mere fact that laws have been posited - ranging from national constitutions to the many different laws governing the diverse and complex spheres of life together in society - also give them legitimacy? Is legality and legitimacy the same? Is justice just another name for "what the courts will do in fact" - in the words of a well-known definition?

There can be little doubt that both in theory and practice these kinds of views are indeed widespread and almost taken for granted by many. It is a position defended by many theorists and scholars. It reflects the way many law students are taught. It is the rule of conduct for many legal practitioners - and the theme of intriguing episodes of many television series - that personal moral convictions and ideas about justice should not play any role in the legal process, but that the only purpose should be the fair and correct 
administration of the existing, positive law of the land. In short, justice is nothing else than the correct application of the positive law.

One could argue that this position is the result of long and complex developments in legal thought and practice in the Western world and the direct legacy of philosophical traditions since Kant and his distinction between legality and morality.

From a theological perspective too, this position found enthusiastic support from those who see the authority of the state - including the authority to make and administer law - as absolute and final. In such a view, the state has divine authority to maintain "law and order" and accordingly the positive law of the land, often even including its application, is safeguarded from any potential criticism.

Such blind trust in the positive law easily hides the historical and the social nature of all existing law. Many laws governing common life in modern societies and most of the regulations and prohibitions that rule the diverse spheres of everyday social life are of course value-neutral. They are merely practical arrangements and do not reflect different worldviews and moral systems. Driving on the left or right side of the road is not an ethical issue - but what about fishing quotas, education policies, punishment, import regulations, asylum and immigration regulations, land reforms, building roads and dams, military spending, gender issues, social security, family law, nature conservation, national research priorities, international covenants to protect natural and cultural diversity?

In a broader, often almost indirect sense, many laws do reflect political priorities, worldviews, specific interests, ethical concerns, notions of justice, agendas of development, transformation, equality, protection, in short, moral perspectives. What is regarded, in any particular society, as existing and therefore positive law, is inevitably always the product of very particular historical developments and very specific social and political interests, commitments and visions.

Small was raising questions about the legitimacy, the morality and the justice of apartheid laws, specifically the Mixed Marriages Act, that became law also in response to appeals from churches, in order to maintain their moral worldview, at the time.

National constitutions provide interesting illustrations. Very often they are popularly portrayed as the final authority and source of all other authority, as simply given, as almost natural and inevitable, as beyond critique and further questioning, in short, as having their own legitimacy through their mere legality. Modern constitutions can easily be viewed and in fact used as the ultimate source and the final norm for morality and justice.

Such a process, however, may hide the fact of their own very particular genesis, the fact that they also need forms of legitimacy, that they too reflect moral worldviews and visions, that they too proclaim specific values and convictions, that they in particular depend on trust, loyalty and commitment, that they call for embodiment, practices and virtues.

The passionate struggle against the old South African constitution with its very particular historical and explicitly religious claim to legitimacy provided an interesting demonstration, as does the language of commitment to our new shared historical experiences and to different values and convictions in our new constitution.

Even constitutions - for many the seemingly ultimate form of legality and even legitimacy - are themselves founded on morality, reflect morality, embody morality, call for morality and depend on morality.

The critical concerns that Small raises - regarding any total identification of legality and legitimacy; regarding any strict separation between legality and morality, between the practice of law and order and questions of justice - should not blind us to the crucial 
importance of existing law for any society and to the importance of an attitude of respect, loyalty and even obedience.

Indeed, what is law without morality, also in this sense of citizens respecting and willingly obeying the law? It is crucially important that people should not regard themselves as above the law, as more moral or more just than the existing law and therefore not themselves subjected to the law, as a law unto themselves that may determine whether and to what extent they will obey specific laws.

It is not without very good reason that this dominant legacy of separating legality and morality developed in Western legal theory and practice.

The law is more general than all particular, whether collective of personal, and therefore conflicting moralities; it does guarantee fairness; it does provide security of expectations; it does promise procedural justice; it does protect freedom; it does contribute to peace; it does maintain order; it does make human life together possible.

Perhaps this is why Small sounds so hesitant? Perhaps his refrain should be read as a real concern, as a real, serious and existential question? Indeed, what abou' de lô?

Still, from a theological perspective, even this respect and loyalty does not exclude the need for the critical questioning also suggested by Small - but, questioning in terms of what? What could be the norm with which to measure the law? What could be the criteria with which to evaluate? It seems that Small may be contemplating three possible answers.

\section{Moral Law?}

Perhaps the phrase dey fell in love already suggests a first criterion? Is Small perhaps alluding to a higher morality here, to a moral law that has precedence over any human regulation and prohibition? Does human love trump all social and even legal prescriptions and expectations? Is there a law of love, attracting two people to one another, irrespective of the moral notions of their respective communities, irrespective of the legal codes in which their communities attempt to organize and protect their moral worldviews?

Or is this perhaps a more general reference to the importance of individual freedom, personal choice, subjective expression, to be followed rather than social codes and human laws?

Is it even more generally therefore an allusion to the ultimate norm of modern consciousness, namely the freedom of conscience?

In the context of the apartheid struggle, it would even make perfect sense to hear here a poetic appeal to conscientious objection, to the ultimate right of the individual to resist, ignore and disobey all immoral authorities and all unjust laws, including what individuals may perceive as the immoral and restrictive codes of religious, moral and legal authorities.

For some theological traditions, all these notions - a higher law of love; individual freedom; freedom of conscience; conscientious objection - may indeed sound plausible and appealing as possible moral criteria by which to measure the legitimacy of all claims to legality.

Experience has shown, however, that one should be very careful with these kinds of argument. Seeing the relation between law and morality in these terms, and appealing to one's own freedom, one's own conscience, one's own moral insight or one's own intuitions and feelings as superior sources of moral orientation carrying more authority for oneself than the moral codes of community and even the positive law in society can be dangerously misleading. 
In fact, it is to a large extent precisely to counter such arbitrary and often very subjective claims to moral superiority that the tradition identifying legality with legitimacy developed.

The critical issue is once again that all these sources of appeal - notions of love; understandings of individual freedom; personal moral visions; subjective hierarchies of moral values, commitments and responsibilities; the category of conscience - are just as historically and socially constructed as the laws they claim to critique.

Therefore, although many religious communities and theological traditions, including major forms of Protestant Christianity, would in principle agree with the theoretical possibility that under extraordinary circumstances it may become necessary for individuals - whether in the name of love, conviction, or conscience - to claim that they have no other choice than political resistance, to the point of conscientious objection and perhaps even civil disobedience, they will also affirm that it is in practice always very problematic to discern when such moments have indeed arisen.

In fact, in this respect the normal relationship between law and morality would rather be the opposite. Law normally trumps personal feelings, individual convictions, and subjective moral visions and values.

Law can even fulfill the role of moral education, formation and transformation. Morality changes, and very often it changes as a result of legal changes. Experience amply shows that forms of racism, sexism, homophobia, xenophobia, prejudice and discrimination, disregard for human dignity, violations of human rights, slavery, abuse, and in fact many practices of corruption, nepotism and exclusion often first have to be prohibited by law, before a major part of the population will change their minds to accept and share these convictions. In this sense, living in a city with just laws is indeed an important form of moral formation - as the Greek philosopher already taught.

Moral assumptions that are kept alive in groups by way of culture and religion, through tradition, custom and authority, may be challenged and transformed through changes in the law. Laws may help to make societies more moral.

Morality, for this reason, shows itself precisely in respect and loyalty to the law, and not in claiming superiority over the law - but again, critics would rightly counter, in the spirit of Adam Small, that this will always depend on the moral quality of the law itself, on the legitimacy of the law.

So, what or who guarantees the legitimacy of what is legal?

In recent years, the social philosopher Jürgen Habermas again raised these questions in interesting ways when he applied his approach called communicative (or discourse) ethics to the field of morality and law. Arguing that legality cannot simply claim legitimacy, but indeed needs forms of legitimation, he considers possible solutions.

Within democratic societies, legitimacy depends on the full and public participation of informed people in the determination of what is legal, of what is law.

But is the legitimacy given simply by the fact that everyone has participated in the process, or does it also depend on the content of their contributions?

Is legitimacy simply the result of true democratic participation and decision-making, in other words based on procedural fairness and full participation? Or is it also dependent on the content of the public debates and decisions, on the substance, the actual results of conversation in the public sphere?

On this point, there remain major differences of opinion. In Small's words, Diana se mense sê/Martin se mense sê/almal die mense sê//maar, what you tol'/what God tell/what man tell/what devil tell/what you tol'? Is it sufficient that everyone speaks and participates, 
or is the question also what they say, on whose behalf they speak, in whose interest, whether what they say is indeed correct, moral, just? Should laws produced by the group, the majority, masses, popular opinion be regarded as moral and just simply because of the democratic process and majority decisions? Or should even the laws of public opinion be subjected to criteria of substance and content?

Many religious communities and theological traditions will be inclined to claim that justice is indeed more than merely formal and procedural - but then, whose justice?

\section{Just Law?}

Is there perhaps - as a second possible answer - some higher justice against which all law and human justice should and could also be measured? Is it possible to agree on the nature and the content of this higher justice? Could such higher justice perhaps be the criterion against which to judge the justice of human practices of justice - for example in the case of Diana and Martin? Watte' lo would this then be?

For a very long time, the tradition that claimed to answer this question and the main alternative position to positive law has been the natural law tradition. Already in classical philosophical forms, and indeed in many and diverse secular versions, although also very influential in religious and theological guise, especially in Catholic moral thought, but indeed also in Protestant variants, this tradition somehow claims that there is access to an understanding of justice through human nature and rational thought.

Again however, this approach to deal with the relation between law and morality (or justice) proves to be deeply problematic too.

Especially from the perspective of recent communitarian thought, it has been demonstrated that notions of nature and reason are never as general, universal and ahistorical as they may seem and sometimes claim. They are inevitably always socially and historically determined, embedded in particular traditions, related to specific communities, only natural and reasonable to some. The question of our access to knowledge of such higher justice always remains a question of whose justice, which rationality, in the words of the moral philosopher Alasdair MacIntyre. Watte' lô?

Even more problematic is the historical experience that notions of natural law have been used to justify convictions and practices that were later regarded by many as unjust and immoral. The theological and ideological uses of natural law arguments, of orders of creation and providence during the Nazi-period as well as during the apartheid decades, remain tragic reminders of this potentially deeply problematic misuse of the notions of nature and reason. Indeed, sê Martin sê Diana/watte' lô/God's lô'/man's lô/devil's lô/watte' lô?

Many people would even argue that natural law argumentation is still being used to justify views and practices of for example cultural oppression, gender discrimination and homophobic prejudice, contradicting what they themselves would see as the higher justice.

But then, what is this higher justice? Many would today probably answer by appealing to notions of human dignity and rights.

Of course, again not everyone would agree. The notion of human dignity may be hard to define, as recent attempts toward a constitution for Europe showed (as well as intense legal debates of the last decade in Germany over the interpretation of Article 1,1 GG).

The broad consensus about the content of human rights does not reflect complete agreement, but rather internal tensions and continuing debate. 
In fact, what seems to many like a consensus is by far not universal, but meets with resistance in many parts of the world, at least with divergent understandings of human rights.

What may now seem like a self-evident and rational expression of natural justice, is in reality also the historical outcome of very particular conflicts. When the new German constitution after the Nazi-atrocities posited in its first article that the dignity of a human being is inalienable (Bonn 1949, unantastbar, cannot be violated), they were not making some objective observation of fact, but rather confessing their deeply held moral commitment for their future live together.

Even for people committed to this understanding of justice - also as norm to measure particular laws - it is therefore not necessarily plausible to found this commitment on claims based on natural law and universal reason. But, on what then?

\section{Divine Law?}

Could the - third - alternative be that true morality or higher justice is of divine nature, somehow founded on God's own revelation or will? Should human laws perhaps be expressions of and therefore measured by God's lô?

For many religions traditions this is indeed the tempting answer, for some even selfevident and obvious. With the present resurgence of religion and the accompanying growingly confident and self-assured claims from many religious groups and communities, this response is indeed increasingly common, popular and challenging. It is challenging, because it is such a deeply problematic response.

In his widely acclaimed study on Moses' legacy (Moses Vermächtnis. Über göttliche und menschliche Gesetze, 2006), Friedrich Wilhelm Graf recently analyzed the nature and implications of these contemporary challenges for democratic and pluralist societies. At stake is indeed the relation between law and morality.

Again, the problems are obvious. Merely the fact of different religious communities with diverse understandings of divine law and revelation in the same pluralist society calls - at least according to democratic philosophical and legal traditions - for ways of separation between legality, that is universal, fair, procedural, and can guarantee peace, on the one hand, and the claims of particular moral and religious views, on the other hand. Gottes Gesetz gibt es nur im Plural (Graf; "God's law is only available in the plural") - that is the challenge, not the solution.

Many historical and contemporary conflicts originate in the unwillingness of religious communities to accept this separation and in their longing to embody their own religious morality in the law of society itself, perhaps because they are the majority, perhaps because only they know the truth.

The need for separation becomes even more obvious in the light of the many historical cases where culture and religion were ideologically used to justify practices, policies and even legal systems embodying what most others would regard as injustice and oppression as What abou' de lô reminds.

However, Small gives a powerful twist to this argument. Diana and Martin commit suicide - obviously as result of human laws, after all, dey go to jail for their love.

Suicide is obviously not against human laws - but what about divine law, what about religious sensitivity and morality? Do many religious traditions not regard suicide as violation against the divine gift of life? 
Martin and Diana died for de lo - but in which way? For which law did they die? Is this not perhaps - given Small's own background and convictions - a deliberately Christian allusion?

Is it without reason that almal die mense sêlo God behoed? When human laws as well as religious morality fail them, is suicide not the ultimate act of faith and trust, thrusting themselves on the divine judgment and promises of justification, because self-saving human obedience has become impossible?

Expressed theologically, Small raises the question whether Christian faith is really about law and morality? For Christian faith, the complex relationship between reg (Recht, law) and geregtigheid (Gerechtigkeit, justice) is only properly considered when their relation to regverdiging (Rechtfertigung, justification) also comes into view.

From this perspective, is divine revelation and will perhaps not primarily about morality, including natural law, but about radical reversal through justification, grace, unconditional acceptance, forgiveness and thus radically new affirmation? From this perspective, which is certainly the perspective of Protestant theology, the crucial questions are not about law and morality, but about law and theology, about law and faith, about law and gospel, about justification and justice, about divine justice and human justice.

The experiences, including the controversies and the continuing conflicts about the South African Truth and Reconciliation Commission still offer one dramatic demonstration of the crucial importance of these questions.

In this powerful way the poem serves as reminder of the so-called Böckenförde thesis, the well-known claim by the former German constitutional judge that free and secular societies live from assumptions which they cannot guarantee themselves.

This thesis was also the theme of the now famous conversation between Habermas and (then still) Joseph Ratzinger (The Dialectics of Secularization, 2007). In important ways, they basically agreed. Democratic, free, pluralist, secular societies are based on presuppositions without which they cannot function or survive - including visions, values, commitments, responsibilities, virtues, concerns, people.

Is this not, after all, why Small wrote this poem? Why he published Kitaar my kruis? Together with his deep respect for existing law, is there not an awareness here that criticism of existing, positive law can become necessary? And is this awareness not based on deep convictions about humanity, morality, justice, religion, and faith? Does this not motivate his critique, his protest? And is it not born from the hope that such protest could make a difference, that society could be renewed, that justice could be better served? Is it not a protest against law in the name of - something?

\section{Some Theological Perspectives}

From the perspective of Protestant Christianity, attitudes of both loyalty (Rechtsloyalität) and reform (Rechtsreform) are seen as extremely important.

Respect and loyalty represent the insight of major legal developments in modernity, underlining the importance of positive law.

Critique and reform represent the insight of different critical traditions, whether in the name of moral systems like natural law, religious traditions, theories of justice, or fundamental democratic assumptions that must continuously be recovered and protected.

Taken together, this calls for forms of legal ethics like Wolfgang Huber's "critical theology of law" (Gerechtigkeit und Recht. Grundlinien christlicher Rechtsethik, 2006). 
For the Reformed tradition, particularly, such an approach to law and morality is central. Calvin himself was a legal scholar and deeply concerned with questions of law and justice. He emphasized obedience, respect and loyalty but simultaneously also freedom, renewal and even the possibility of civil disobedience. The first Reformed ethics in history was in fact written by a legal scholar, for the purpose of social and legal reconstruction during times of social chaos and threatening disorder (see Strohm, Ethik im frühen Calvinismus, 1996, also 2004).

Christian faith does not have its own theory of justice (Graf, Protestantismus und Rechtsordnung, 2007). Based on the witness of the biblical traditions of both the Old and New Testaments, it rather affirms legal theories and practices that seem to support central Christian perspectives and critiques legal theories and practices whenever they seem to contradict central Christian perspectives.

Throughout history, this meant that Christian faith always engaged with the legal and moral theories and practices of different times and places, sometimes affirming, sometimes critiquing. The complex relations between theology and - for example - theories of justice from Aristotle and the classical tradition; natural law thinking; Kant, Hegel and modernity; notions of human dignity and rights; and contemporary debates on economic justice and compassionate justice for the suffering all illustrate these ambiguous relations. This would lead to major disagreements in the Christian church.

In the Reformed faith, the inclination has mostly been to view questions of justice and morality from the perspective of salvation, rather than creation. In practice, this leads to major differences between Christian and theological traditions and communities. The theological struggle over the biblical justification of apartheid had much to do with this fundamental distinction.

Major Reformed theologians (like Karl Barth, Reinhold Niebuhr, Allan Boesak) and major events and places in the history of Reformed churches (Barmen, Belhar, Debrecen, Accra) stand for such debates about the critical implications of the gospel of salvation for life together in society, and therefore for questions of law, morality and faith.

In the poetic words of Adam Small one unmistakably hears the voice of this Reformed tradition.

\section{BIBLIOGRAPHY}

Alexy, R 2002. "Recht und Moral" in Härle \& Preul, 83-92.

Barth, K 1968. Community, State, and Church. Peter Smit, Gloucester.

Brady, BV 1998. The moral bond of community. Justice and discourse in Christian morality. Georgetown University Press, Washington, DC.

Dabrock, P, Jähnichen, T, Klinnert, L \& Maaser, W (Hrsg.) 2003. Kriterien der Gerechtigkeit. Chr. Kaiser/Gütersloher Verlagshaus, Gütersloh.

De Villiers, E \& Kinghorn, J (reds.) Op die skaal: gemengde huwelike en ontug. Tafelberg, Kaapstad, 1984.

Dunstan, J 1979. "A South African dramatist's critical look at Calvinism. Adam Small's 'The orange earth."' JTSA, Vol 27/1, 20-25.

Eco, U 2001. Five Moral Pieces. Secker \& Warburg, London.

Forrester, DB 1997. Christian justice and public policy. Cambridge University Press, Cambridge. 
Graf, FW 2006. Moses Vermächtnis. Über gottliche und menschliche Gesetze. Verlag CH Beck.

Graf, FW 2007. "Protestantismus und Rechtsordnung" (still unpublished paper).

Habermas, J 2005. Democracy and the public Sphere. Pluto Press, London.

Habermas, J 1986. Law and morality. The Tanner Lectures on Human Values, Harvard University, October 1 and 2.

Habermas, J \& Ratzinger 2007. J The dialectics of secularisation. Ignatius Press, San Francisco.

Härle, W \& Preul, R (Hrsg.) 2002. Ethik und Recht. Elwert, Marburg.

Hardmeier, HVC, Kessler, R \& Ruwe, A (Hrsg.) 2003. Freiheit und Recht. Chr. Kaiser, München.

Herms, E 2002. Theologische Ethik und Rechtsbegründung in Härle \& Preul, 13-40.

Hesselink, IJ 1992. Calvin's concept of the law. Pickwick, Allison Park.

Höffe, O 2001. Gerechtigkeit. Verlag CH Beck, München.

Horn, C \& Scarano, N 2002. Philosophie der Gerechtigkeit. Suhrkamp, Frankfurt.

Horster, D 2006. Jürgen Habermas und der Papst. Transcript Verlag, Bielefeld.

Huber, W 2006. Gerechtigkeit und Recht. Chr. Kaiser, Gütersloh.

Hund, J 1988. Law and Justice in South Africa. Institute for Public Interest Law and Research, Johannesburg.

Joas, H 2000. The genesis of values. University of Chicago Press, Chicago.

Joas, H \& Wiegandt, K 2005. Die kulturellen Werte Europas. Fischer Taschenbuch Verlag, Frankfurt.

Lebacqz, K 1986. Six Theories of Justice. Augsburg Publishing House, Minneapolis.

Lebacqz, K 1987. Justice in an unjust world. Augsburg Publishing House, Minneapolis.

Lienemann, W 1995. Gerechtigkeit. Vandenhoeck \& Ruprecht, Göttingen.

MacIntyre, A 1988. Whose justice? Which rationality? University of Notre Dame Press, Notre Dame.

Nemoianu, V 2006. "The church and the secular establishment. A philosophical dialog between Joseph Ratzinger and Jürgen Habermas.” Logos 9:2, Spring, 17-42.

Nissen, U, Andersen, S \& Reuter, L (eds.) 2003. The Sources of public Morality On the ethics and religion debate. Lit Verlag, Münster.

Porter, J 1999. Natural \& Divine Law. William B Eerdmans, Grand Rapids.

Rawls, J 1999. "The idea of public reason revisited" in The law of peoples, Harvard University Press, Cambridge.

Schreiner, SE 1991. The theater of his glory. Baker Academic Press, Grand Rapids.

Small, A 1961. Kitaar my kruis. HAUM, Kaapstad.

Smit, DJ 1974. Demokrasie en dialoog. Ongepubliseerde magister-tesis, Stellenbosch Universiteit.

Smit, DJ 2005. "On social and economic justice in South Africa today. A theological perspective on theoretical paradigms" in Theories of Social and Economic Justice, ed. AJ van der Walt, Sun Press, Stellenbosch, 225-238.

Smit, DJ 2007. "Notions of the public and doing theology." International Journal of Public Theology, Vol. 1. No. 3-4, 431-454.

Strohm, C 1996. Ethik im frühen Calvinismus. Humanistische Einflüsse, philosophische, juristische und theologische Argumentation sowie mentalitätsgeschichtliche Aspekte 
am Beispiel des Calvin-Schülers Lambertus Danaeus. De Gruyter, Berlin/New York.

Strohm, C 2004. "Methodology in discussion of "Calvin and Calvinism"' in HJ Selderhuis (ed.), Calvinus Praeceptor Ecclesiae. Papers of the International Congress on Calvin Research, THR 388, 65-105.

Van Wyk, S 2006. "Die groot Small - oor die lewe en werk van Adam Small" (http://www.;litnet.co.za, 28 Maart).

Vosskuhle, A 2006. "Ist das Öffentliche Wirtschaftsrecht moralisch?" in Wirtschaft im offenen Verfassungsstaat, Festschrift für Reiner Schmidt zum 70. Geburtstag, Hrsg. H Bauer, D Czybulka, W Kahl, A Vosskuhle, CH Beck, München, 609-626.

Walzer, M 1983. Spheres of Justice. Basic Books, New York.

Welker, M 2002. "Moral, Recht und Ethos in evangelisch-theologischer Sicht" in Härle \& Preul, 67-82.

Welker, M 1997. "Recht in den biblischen Überlieferungen in systematisch-theologischer Sicht" in Das Recht der Kirche. Band I, Hrsg. G Rau, H-R Reuter \& K Schlaich, Chr Kaiser Verlag/Gütersloher Verlag, Gütersloh, 390-414.

Welker, M 2002. "Wovon der freiheitlichen Staat lebt. Die Quellen politischer Loyalität im spätmodernen Pluralismus" in HR Reuter u.a. (Hrsg.), Freiheit verantworten. Festschrift für Wolfgang Huber zum 60. Geburtstag, Chr. Kaiser: Gütersloh, 225-242. 